\title{
A new Cd(II)-containing ionic liquid: Synthesis, characterization and electrocatalysis
}

\author{
RUIRUI ZHUANG, FANGFANG JIAN* and KEFEI WANG \\ New Materials and Function Coordination Chemistry Laboratory, \\ Qingdao University of Science and Technology, Qingdao Shandong 266042, P.R. China \\ e-mail: ffj2003@163169.net
}

MS received 18 June 2009; revised 26 December 2009; accepted 4 January 2010

\begin{abstract}
The present work reports on the synthesis, characterization and performance of a new metal-containing ionic liquid $\left[\left(\mathrm{C}_{4} \mathrm{H}_{9}\right)_{2}\right.$-bta] $\left[\left(\mathrm{C}_{4} \mathrm{H}_{9}\right.\right.$-bta $\left.) \mathrm{CdCl}_{3}\right]$ (bta = benzotriazole) as electrocatalyst for hydrogen peroxide reduction. The structure of the $\mathrm{Cd}(\mathrm{II})$-containing ionic liquid (Cd-IL) has been characterized by X-ray crystallography, IR spectroscopy and elemental analysis. The molecule contains one 1,3-dibutyl-benzotriazolium cation and an anionic $\mathrm{Cd}$ coordination entry. The electrochemical property of Cd-IL bulk-modified carbon paste electrode (Cd-IL/CPE) has been studied by cyclic voltammetry. The $\mathrm{Cd}-\mathrm{IL}$ has functions both as a binder and an electrocatalyst. The Cd-IL/CPE shows good electrocatalytic activity towards the reduction of hydrogen peroxide.
\end{abstract}

Keywords. Metal-containing ionic liquid; cadmium chloride; crystal structure; electrocatalysis.

\section{Introduction}

Ionic liquids (ILs) have attracted much attention as potential solvents and reaction media for organic synthesis, catalysis, electrochemistry, and solvent extraction, due to their unique chemical and physical properties such as tunable acidity, low vapor pressure, non-flammability, a wide liquid-state temperature range, and extended electrochemical windows. ${ }^{1-4}$ In recent years ILs have also been used as solvents for the synthesis of nanomaterials, ${ }^{5-9}$ and inorganic as well as hybrid framework solids. ${ }^{10-15}$ And their unique properties have been understood on the basis of the interactions between the cations and the anions which determine the nature and dominance of the supramolecular self-assembling forces. ${ }^{16,17}$ The role of electrostatic, hydrogen bonding, hydrophobic and other interactions has been examined, along with aspects related to factors such as the length of the alkyl chain, nature of the anion, polymorphism, and structural disorder ${ }^{18,19}$ Co-crystal of an ionic liquid with organic molecules as mimic of ionic liquid solution was also investigated. ${ }^{20}$

Metal-containing ionic liquids are regarded as promising new materials that combine the properties of ionic liquids with additional intrinsic magnetic,

*For correspondence spectroscopic, or catalytic properties depending on the enclosed metal ion. ${ }^{21-24}$ Many of metalcontaining ILs are capable of mediating a wide variety of synthetic reactions and exhibit great potential in organometallic chemistry and catalysis. ${ }^{25}$ ILs of imidazolium salts composed of various metal components have been reviewed; some examples include halides of $\mathrm{V}, \mathrm{Fe}, \mathrm{Co}, \mathrm{Ni}, \mathrm{Cu}, \mathrm{Zn}, \mathrm{Sn}, \mathrm{In}, \mathrm{Pt}, \mathrm{Pd}$ and $\mathrm{Au}$ and carbonyls of $\mathrm{Co}$ and $\mathrm{Rh}^{25}$ The lead bromide derivatives [emim] $\left[\mathrm{PbBr}_{3}\right](\mathrm{emim}=1$-ethyl3 -methylimidazole) and $[\mathrm{bmim}]_{2}\left[\mathrm{PbBr}_{4}\right](\mathrm{bmim}=1$ butyl-3-methylimidazole) were reported as to show supramolecular organization and behave as ionic liquids. ${ }^{26}$ Martin's group reported a series of metalcontaining ionic liquid crystals formed by surfactant templating of molten metal halides (including $\mathrm{Zn}$, $\mathrm{Cd}, \mathrm{Cu}, \mathrm{Ni}, \mathrm{Co}, \mathrm{Fe}$ and $\mathrm{Mn}){ }^{27}$ Tang and Madring have synthesized two cyano-containing compounds, reacted them with cadmium chloride and obtained two new cadmium-containing ionic liquids. ${ }^{28}$ Our group has studied the electrocatalytic reduction of hydrogen peroxide and bromate by a binuclear $\mathrm{Cd}(\mathrm{II})$-containing ionic liquid modified electrode ${ }^{29}$ and a $\mathrm{La}(\mathrm{III})$-containing ionic liquid bulk-modified carbon paste electrode. ${ }^{30}$

The present work we report the synthesis and crystal structure of $\left[\left(\mathrm{C}_{4} \mathrm{H}_{9}\right)_{2}\right.$-bta $]\left[\left(\mathrm{C}_{4} \mathrm{H}_{9}\right.\right.$-bta $\left.) \mathrm{CdCl}_{3}\right]$, 
and the use of this new metal-containing ionic liquid as a bulk-modifier to fabricate a chemically modified carbon paste electrode by direct mixing. The metal-containing ionic liquid has double functions of a binder and an electrocatalyst. This modified electrode shows electrocatalytic activity towards the reduction of hydrogen peroxide. A possible mechanism for the reaction is proposed.

\section{Experimental}

\subsection{Chemicals and measurement}

All the chemicals were of analytical reagent grade and used without further purification. Elemental analysis were performed with a Perkin-Elmer 1400C analyzer (USA). Infrared spectra were recorded on a Nicolet 170SX spectrometer (USA) using pressed $\mathrm{KBr}$ plates in the range of $4000-400 \mathrm{~cm}^{-1}$. Thermal gravimetric analysis (TGA) was performed on an SDT 2980 with $c a 10 \mathrm{mg}$ of samples under nitrogen atmosphere $\left(150 \mathrm{~mL} \mathrm{~min}^{-1}\right)$ at a heating rate of $10^{\circ} \mathrm{C} \mathrm{m^{-1 }}$. Conductivity measurement was performed using DZS-707 multi-parameter water quality analysis instrument (Shanghai Precision and Scientific Instrument Co., Ltd.). Conductivity cell was calibrated with $\mathrm{KCl}$ solution. Electrochemical measurements were performed at $25 \pm 2{ }^{\circ} \mathrm{C}$ on an Autolab PGSTAT-30 digital potentiostat/galvanostat, (EcoChemie BV, Utrecht, Netherlands). A threeelectrode cell was used in the experiments. The working and counter electrodes were $\mathrm{Cd}-\mathrm{IL} / \mathrm{CPE}$ and a platinum wire respectively. The reference electrode was an $\mathrm{Ag} \mid \mathrm{AgCl}, \mathrm{KCl}(1 \mathrm{M}) \|$, and all the potentials reported in this work were measured relative to this electrode $\left(236.3 \mathrm{mV} / \mathrm{SHE}\right.$ at $\left.25^{\circ} \mathrm{C}\right)$. 0.1 M, pH 6.1 Britton-Robinson (B-R) buffer solution was used as the supporting electrolyte. All the solutions were deaerated with pure nitrogen for 30 minutes and kept under nitrogen atmosphere during the experiments.

\subsection{Preparation and physical measurement of Cd-IL}

Cadmiun chloride (114.1 mg, 0.5 mmol), 1-butylbenzotriazole $(87.5 \mathrm{mg}, 0.5 \mathrm{mmol})$ and 1,3-dibutylbenzotriazolium $(231.0 \mathrm{mg}, 1 \mathrm{mmol})$ were dissolved in $40 \mathrm{~mL}$ of ethanol solution. The so which was stirred for $2 \mathrm{~h}$, and the resulting white precipitate was separated by filtration. Recrystallization of white precipitated from acetonitrile gave $\mathrm{Cd}-\mathrm{IL}$ in $78 \%$ yield. The melting point of $\mathrm{Cd}-\mathrm{IL}$ was $112^{\circ} \mathrm{C}$. The $\mathrm{C}, \mathrm{H}$ and $\mathrm{N}$ contents were determined by elemental analysis (calculated for $\mathrm{C}_{24} \mathrm{H}_{35} \mathrm{CdCl}_{3} \mathrm{~N}_{6}$ (\%) C $46.02, \mathrm{H} \mathrm{5.63,} \mathrm{N} \mathrm{13.42;} \mathrm{measured:} \mathrm{C} 46.05, \mathrm{H}$ $5.61, \mathrm{~N} \mathrm{13.39)}$. The IR spectrum, band at $3039 \mathrm{~cm}^{-1}$ which was assigned to the $\mathrm{C}-\mathrm{H}$ stretching vibration of the benzene ring. The bands at 2958 and $2872 \mathrm{~cm}^{-1}$ were attributed to the $\mathrm{C}-\mathrm{H}$ stretching vibrations of the alkyl group. Several bands appeared in the $1608 \sim 1456 \mathrm{~cm}^{-1}$ range, which arise from the vibrations of the benzene ring skeleton.

$\mathrm{X}$-ray diffraction data were ascertained with a graphite monochromator at $20^{\circ} \mathrm{C}$ using $\mathrm{MoK}_{\alpha}$ radiation $(\lambda=0.71073 \AA)$. The structure of $\mathrm{Cd}$-IL was solved by direct methods and refined by least squares on $F_{\text {obs }}{ }^{2}$ by using the SHELXTL software package. ${ }^{31}$ All non-hydrogen atoms were refined anisotropically, and the hydrogen atoms were placed in calculated position and allowed to ride on their parent atoms. The molecular graphics was plotted using the SHELXTL. Atomic scattering factors and anomalous dispersion corrections were taken from the International tables for X-ray crystallography. ${ }^{32}$

\subsection{Preparation of $C d-I L / C P E$}

The traditional CPE was prepared by hand-mixing of graphite powder with paraffin at a ratio of $70: 30$ $(w / w)$ in an agate mortar. The homogeneous carbon paste was packed into a cavity of a glass tube (inner diameter $3 \mathrm{~mm}$ ). The electrical contact was provided by a copper stick. The $\mathrm{Cd}-\mathrm{IL}$ was employed to fabricate modified carbon paste electrodes by the following procedure: $0.4 \mathrm{~g}$ of graphite powder and $0.1 \mathrm{~g}$ of $\mathrm{Cd}-\mathrm{IL}$ were mixed thoroughly in a mortar and heated at $120^{\circ} \mathrm{C}$ to form a homogeneous carbon paste. A portion of the carbon paste was filled into one end of a glass tube (inner diameter $3 \mathrm{~mm}$ ) and a copper stick was inserted through the opposite end to establish an electrical contact. The Cd-IL/CPE surface was smoothed on a piece of weighing paper until it had a shiny surface we used.

Different ratios Cd-IL $(6: 1,5: 1,4: 1$ and $3: 1$ $(\mathrm{w} / \mathrm{w}))$ of graphite powder and found that the optimum preparative condition was $4: 1$. When the amount of the Cd-IL was too small, the adhesion of graphite start when the amount of the Cd-IL was too large, the mechanical strength of carbon paste was too small and it was difficult to shape it. 


\section{Results and discussion}

\subsection{Crystal structure of $C d-I L$}

The molecular structure of $\mathrm{Cd}-\mathrm{IL}$ with the atomic numbering scheme is shown in figure 1. Crystal data and structure refinement are listed in table 1. Molecule, consists of one cation of 1,3-dibutyl-benzotriazolium and one anion which is a $\mathrm{Cd}$ containing coordination entity. The $\mathrm{Cd}$ atom adopts a distorted tetrahedral geometry by coordinating to three chlorine atoms and one nitrogen atom from 1-butylbenzotriazole, which is further linked to 1,3-dibutylbenzotriazolium through cation via $\mathrm{C}-\mathrm{H}$... $\mathrm{Cl}$ hydrogen bonds. The bond lengths and bond angles around the $\mathrm{Cd}$ center are unexceptional and are comparable to those observed for analogs complexes. The crystal packing drawing of Cd-IL is shown in figure 2 . There are two weak potentially intramolecular $\mathrm{C}-\mathrm{H} \cdots \mathrm{Cl}$ hydrogen bonds interactions, with the donor-acceptor distances of $3.2697 \AA$ for $\mathrm{C}(11 \mathrm{~A}) \cdots \mathrm{Cl}(3)$ and $2.9165 \AA$ for $\mathrm{C}(12 \mathrm{~A}) \cdots \mathrm{Cl}(3)$. There are also two weak potentially intermolecular $\mathrm{C}-\mathrm{H} \cdots \mathrm{Cl}$ hydrogen bonds interactions, with the donor-acceptor distances of $2.9045 \AA$ for C(11A) $\cdots$ $\mathrm{Cl}(2)$ and $3.1154 \AA$ for $\mathrm{C}(13 \mathrm{~A}) \cdots \mathrm{Cl}(2)$. The $\mathrm{H} \cdots \mathrm{Cl}$ distances of both intramolecular and intermolecular interactions are in the range of 2.21-2.73 $\AA$. The $\mathrm{C}-\mathrm{H} \cdots \mathrm{Cl}$ hydrogen bonds has attracted much interest since the hemoglobin acceptor capability of terminal

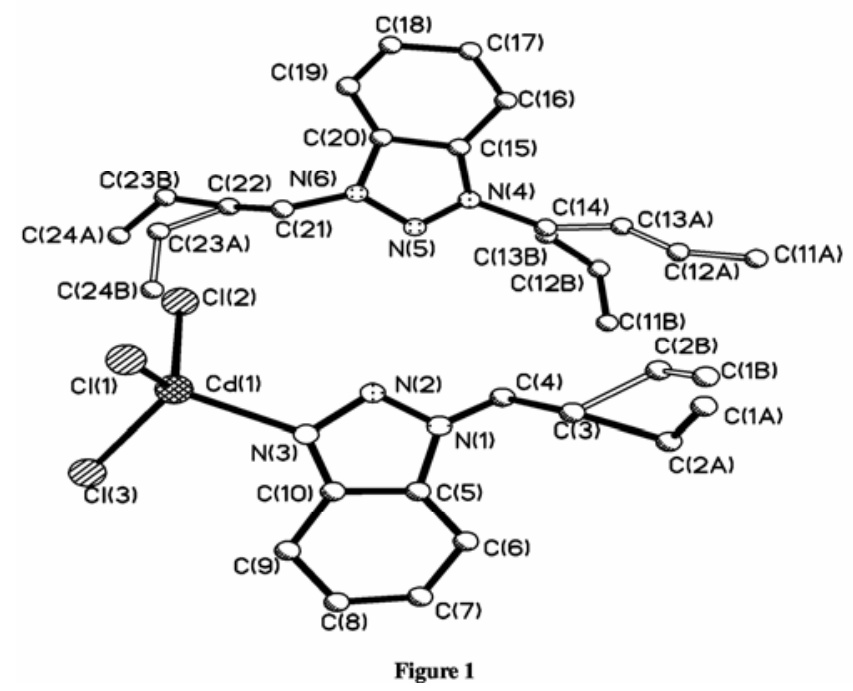

Figure 1. The molecular structure of $\left[\left(\mathrm{C}_{4} \mathrm{H}_{9}\right)_{2}\right.$-bta] $\left[\left(\mathrm{C}_{4} \mathrm{H}_{9}-\mathrm{bta}\right) \mathrm{CdCl}_{3}\right]$ showing the atom labelling scheme. All the atoms are represented as thermal ellipsoids at $30 \%$ level. metal-bound chlorine $(\mathrm{M}-\mathrm{Cl})$ is stronger than their $\mathrm{C}-\mathrm{Cl}$ analogues. ${ }^{33,34}$ There are four types of $\pi-\pi$ stacking interactions between triazole ring, benzene ring and phenyl ring. The center-to-center distances are in the range of 3.5429-3.5480 $\AA$. The shortest interplanar distances above are in the range of 3.436-3.509 Å.

\subsection{Thermal analysis}

The thermal gravity analysis curve of Cd-IL under a nitrogen atmosphere at a heating rate of $10^{\circ} \mathrm{C} \mathrm{min}^{-1}$ is shown in figure 3 . There were three main steps of weight loss, and the decomposition events took

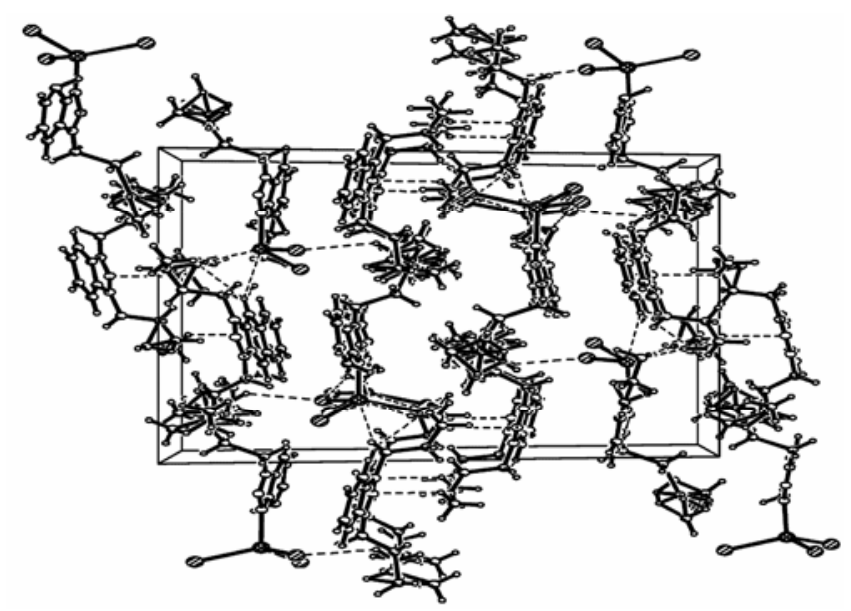

Figure 2. Crystal packing diagram of the unit cell of $\left[\left(\mathrm{C}_{4} \mathrm{H}_{9}\right)_{2}\right.$-bta] $\left[\left(\mathrm{C}_{4} \mathrm{H}_{9}\right.\right.$-bta) $\left.\mathrm{CdCl}_{3}\right]$ along the $a$ axis.

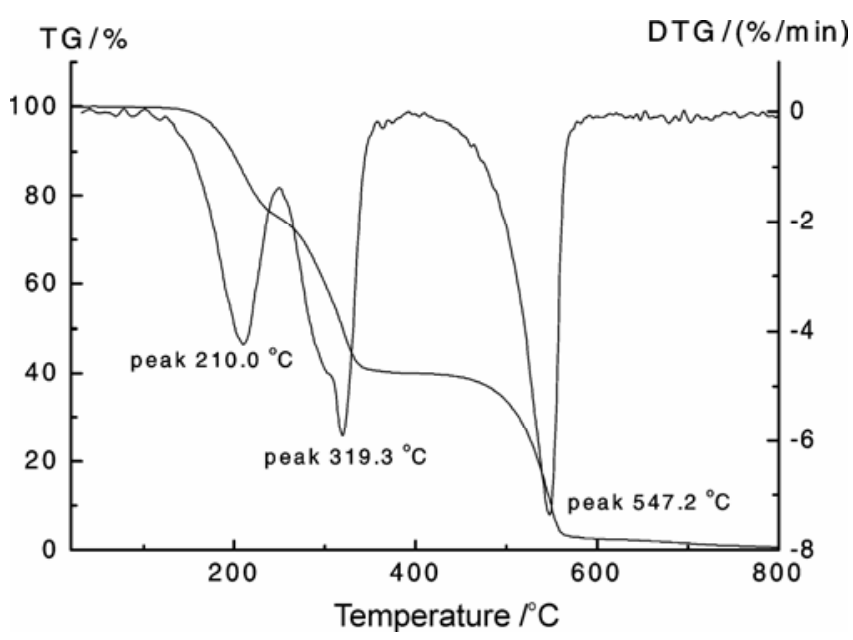

Figure 3. Thermogravimetric analysis curve of $\left[\left(\mathrm{C}_{4} \mathrm{H}_{9}\right)_{2}-\right.$ bta] $\left[\left(\mathrm{C}_{4} \mathrm{H}_{9}\right.\right.$-bta $\left.) \mathrm{CdCl}_{3}\right]$ under a nitrogen atmosphere $\left(150 \mathrm{~mL} \mathrm{~min}{ }^{-1}\right)$ at a heating rate of $10^{\circ} \mathrm{C} \mathrm{min}^{-1}$. 
Table 1. Crystal data and structure refinement for $\left[\left(\mathrm{C}_{4} \mathrm{H}_{9}\right)_{2}-\right.$ bta] $\left[\left(\mathrm{C}_{4} \mathrm{H}_{9}-\mathrm{bta}\right) \mathrm{CdCl}_{3}\right]$.

\begin{tabular}{ll}
\hline Empirical formula & \multicolumn{1}{c}{$\mathrm{C}_{24} \mathrm{H}_{35} \mathrm{CdCl}_{3} \mathrm{~N}_{6}$} \\
\hline Formula weight & $626 \cdot 33$ \\
Temperature $(\mathrm{K})$ & $293(2)$ \\
Wavelength $(\AA)$ & $0 \cdot 71073$ \\
Crystal system, space group & Monoclinic, $P 2_{1} / c$ \\
Unit cell dimensions & \\
$a(\AA)$ & $8 \cdot 5393(9)$ \\
$b(\AA)$ & $17 \cdot 643(2)$ \\
$c(\AA)$ & $20 \cdot 013(2)$ \\
$\beta\left({ }^{\circ}\right)$ & $103 \cdot 411(4)$ \\
Volume $\left(\AA^{3}\right)$ & $2933 \cdot 0(5)$ \\
$Z$, Calculated density $\left(\mathrm{g} \mathrm{cm}{ }^{-3}\right)$ & $4,1 \cdot 418$ \\
Absorption coefficient $\left(\mathrm{mm}^{-1}\right)$ & $1 \cdot 041$ \\
$F(000)$ & 1280 \\
Theta range for data collection $\left(^{\circ}\right)$ & $1 \cdot 56$ to $25 \cdot 50$ \\
Limiting indices & $-9 \leq h \leq 10,-21 \leq k \leq 19,-24 \leq l \leq 24$ \\
Reflections collected/unique & $15737 / 5426\left[R_{(\text {int })}=0 \cdot 0305\right]$ \\
Completeness to $\theta=25 \cdot 50(\%)$ & $99 \cdot 3$ \\
Refinement method & Full-matrix least-squares on $F^{2}$ \\
Data/restraints/parameters & $5426 / 14 / 306$ \\
Goodness-of-fit on $F^{2}$ & $1 \cdot 767$ \\
Final $R$ indices $[I>2 \sigma(I)]$ & $R_{1}=0 \cdot 1513, w R_{2}=0 \cdot 3907$ \\
$R$ indices (all data) & $R_{1}=0 \cdot 1836, w R_{2}=0 \cdot 4272$ \\
Extinction coefficient & $0 \cdot 020(7)$ \\
Largest diff. peak and hole $\left(\mathrm{e} \AA^{-3}\right)$ & $5 \cdot 354$ and $-2 \cdot 033$ \\
\hline
\end{tabular}

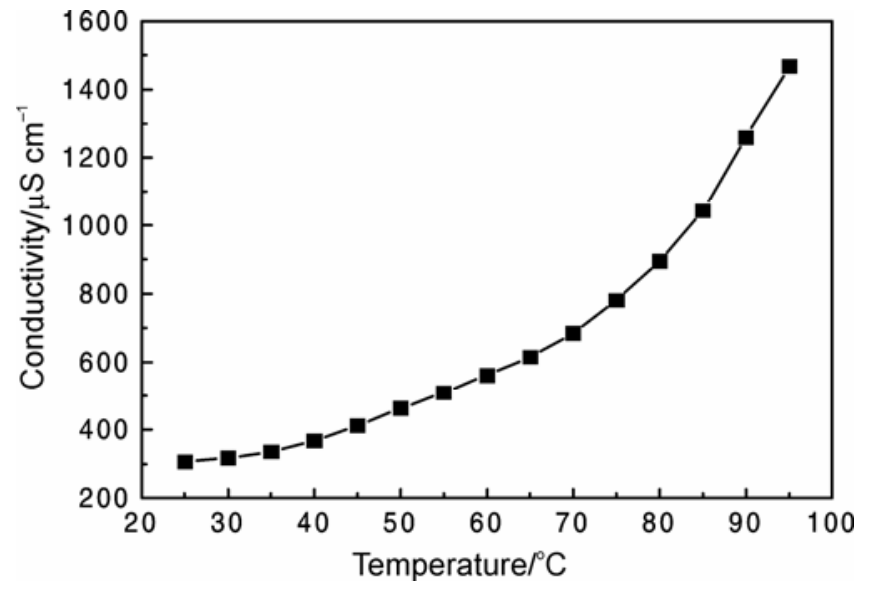

Figure 4. Plot of conductivity of $1 \times 10^{-3} \mathrm{M}\left[\left(\mathrm{C}_{4} \mathrm{H}_{9}\right)_{2}\right.$ bta] $\left[\left(\mathrm{C}_{4} \mathrm{H}_{9}\right.\right.$-bta $\left.) \mathrm{CdCl}_{3}\right]$ in ethanol solution with temperature increasing in the range $\left(25-95^{\circ} \mathrm{C}\right)$.

place at $210 \cdot 0^{\circ} \mathrm{C}, 319 \cdot 3^{\circ} \mathrm{C}$ and $547 \cdot 2^{\circ} \mathrm{C}$. On the base of weight changes, the first process was attributed to the loss of 1-butyl-benzotriazole (found 24.94\% calc. $27.98 \%$ ). The second event corresponded to the loss of 1,3-dibutyl-benzotriazolium (found 35.09\% calc. $37.09 \%$ ). The weight loss during $400^{\circ} \mathrm{C}$ to $800^{\circ} \mathrm{C}$ was attributed to the decomposition of cadmiun chloride and the loss of chlorine and cadmium.
There was no residue at the end owing to sublimation of cadmiun at high temperature.

\subsection{Conductivity}

Because the melting point of Cd-IL is relatively high, it is difficult to study the conductivity of a pure specimen according to VTF-type (VogelTamman-Fulcher) equation. ${ }^{35}$ As a result, it has to be studied in ethanol solution (figure 4). The conductivity of Cd-IL was measured in absolute ethanol from $25^{\circ} \mathrm{C}$ to $95^{\circ} \mathrm{C}$. The conductivity increased with temperature observed for other and comparable to that metal-containing ionic liquids. ${ }^{36}$

\subsection{Electrochemical behaviour of $C d-I L / C P E$}

The electrochemical behaviour of the Cd-IL/CPE was investigated by cyclic voltammetry in the aqueous solution. We chose a $0.1 \mathrm{M} \mathrm{KCl}$ aqueous solution, $0 \cdot 1 \mathrm{M}, \mathrm{pH} 7 \cdot 0$, Britton-Robinson (B-R) buffer solution and $0 \cdot 1 \mathrm{M}, \mathrm{pH} 7 \cdot 0$, phosphate buffer solution as the supporting electrolyte. The modified electrode in B-R buffer solution showed strong current response and symmetric peak shape. Investi- 
gated the electrochemical behaviour of modified CPE in the $\mathrm{pH}$ range from 4.0 to $8.0 \mathrm{~B}-\mathrm{R}$ buffer solution and found that the electrochemical signal was relatively stable at $\mathrm{pH} 6 \cdot 1$. Therefore, we studied the electrochemical behaviour and electrocatalytic properties in $0 \cdot 1 \mathrm{M}, \mathrm{pH} 6 \cdot 1, \mathrm{~B}-\mathrm{R}$ buffer solution.

The cyclic voltammograms (CVs) $\mathrm{Cd}-\mathrm{IL} / \mathrm{CPE}$ are shown in figure 5 . In the potential range from $0 \cdot 2$ to $-1.6 \mathrm{~V}$, curve a had a couple of well-defined redox peaks at $-0.784 \mathrm{~V}$ and $-0.582 \mathrm{~V}$ when the scan rate was $0.05 \mathrm{~V} \mathrm{~s}^{-1}$, with the formal potential $\left(E^{0^{\prime}}\right)$ at $-0.683 \mathrm{~V}$, corresponding to the electrochemical process of $\mathrm{Cd}(\mathrm{II}) / \mathrm{Cd}(\mathrm{I}){ }^{29}$ The separation of the cathodic and anodic peak potential, $\Delta E=0.202 \mathrm{~V}$, $i_{\mathrm{pa}} / i_{\mathrm{pc}}=1.07$, indicates that the electrochemical behaviour of $\mathrm{Cd}-\mathrm{IL} / \mathrm{CPE}$ was quasi-reversible.

The effect of scan rate on the electrochemical behaviour of the Cd-IL/CPE is shown in figure 5 . When the scan rate was varied from 0.05 to $0 \cdot 10 \mathrm{~V} \mathrm{~s}^{-1}$, the peak potentials changed gradually: the cathodic peak potentials shifted to the negative direction and the corresponding anodic peak potentials shifted to the positive direction with increasing scan rate. The plot of peak current versus scan rate is shown in the inset of figure 5. The anodic and cathodic currents are proportional to the scan rates, suggesting that the redox process is confined to the surface.

\subsection{Electrocatalytic effect on reduction of hydrogen peroxide}

Determination of hydrogen peroxide of practical importance because it is the product of reactions catalysed by a large number of oxidases, and is essential in food, pharmaceutical and environmental analysis. ${ }^{37}$ The electroreduction of hydrogen peroxide requires a large overpotential, and no obvious response is observed on a bare CPE.

The electrocatalytic activity of $\mathrm{Cd}-\mathrm{IL} / \mathrm{CPE}$ towards hydrogen peroxide was investigated and results are shown in figure 6 . Curve a was the $\mathrm{CV}$ of $\mathrm{Cd}-\mathrm{IL} / \mathrm{CPE}$ in $0 \cdot 1 \mathrm{M}$, pH $6 \cdot 1$, B-R buffer solution without hydrogen peroxide when the scan rate was $0 \cdot 10 \mathrm{~V} \mathrm{~s}^{-1}$. With the addition of hydrogen peroxide (curves $\mathrm{b}-\mathrm{e}$ ), the peak potential changed reshuffle, suggesting that the Cd-IL was still stable under this reaction. The reduction peak currents increased markedly while the corresponding oxidation peak decreased, which indicated that Cd-IL/CPE showed good electrocatalytic activity towards the reduction of hydrogen peroxide. The possible reaction processes could be described using the following equations: ${ }^{29}$

$$
\begin{aligned}
& \mathrm{Cd}(\mathrm{II})-\mathrm{IL}+\mathrm{e}^{-} \rightarrow \mathrm{Cd}(\mathrm{I})-\mathrm{IL} \\
& 2 \mathrm{Cd}(\mathrm{I})-\mathrm{IL}+\mathrm{H}_{2} \mathrm{O}_{2}+2 \mathrm{H}^{+} \rightarrow 2 \mathrm{Cd}(\mathrm{II})-\mathrm{IL}+2 \mathrm{H}_{2} \mathrm{O} .
\end{aligned}
$$

The inset of figure 6 shows that the catalytic current varies linear with hydrogen peroxide concentration

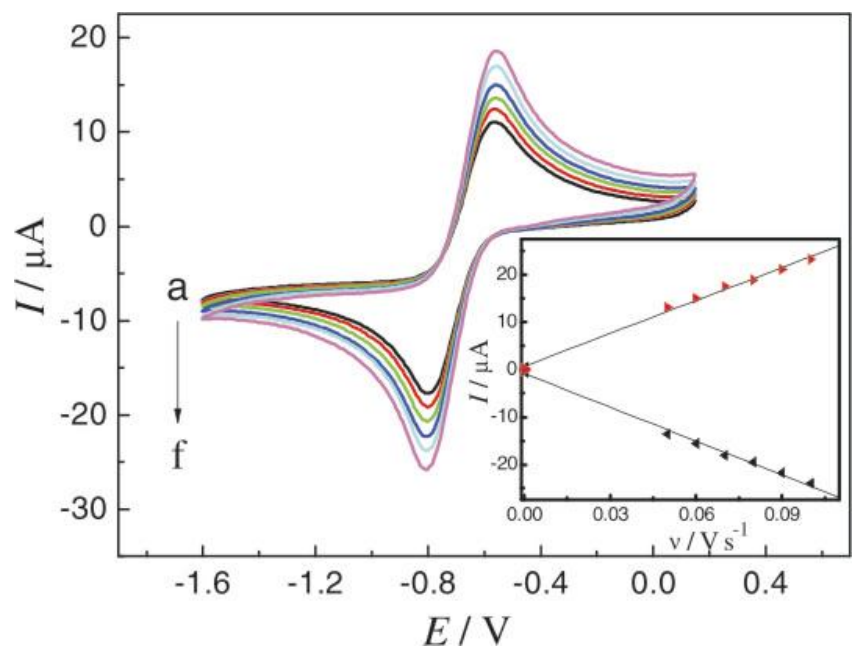

Figure 5. CVs of $\mathrm{Cd}-\mathrm{IL} / \mathrm{CPE}$ in $0.1 \mathrm{M}, \mathrm{pH} 6 \cdot 1 \mathrm{~B}-\mathrm{R}$ buffer solution. Curves (a-f) correspond to the scan rates $0 \cdot 05,0 \cdot 06,0 \cdot 07,0 \cdot 08,0.09$ and $0 \cdot 10 \mathrm{~V} \mathrm{~s}^{-1}$. Inset: the peak current vs scan rate.

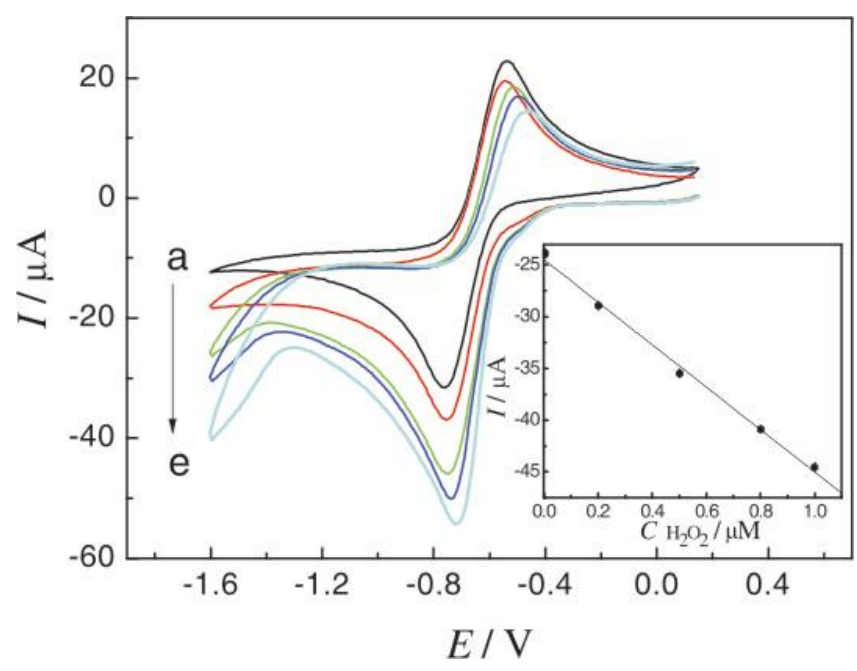

Figure 6. $\mathrm{CVs}$ of $\mathrm{Cd}-\mathrm{IL} / \mathrm{CPE}$ in $0.1 \mathrm{M}, \mathrm{pH} 6 \cdot 1 \mathrm{~B}-\mathrm{R}$ buffer solution containing (a-e) $0,0 \cdot 20,0 \cdot 50,0 \cdot 80$ and $1.00 \mu \mathrm{M}$ hydrogen peroxide with the scan rate as $0 \cdot 10 \mathrm{~V} \mathrm{~s}^{-1}$. Inset: the cathodic peak current vs hydrogen peroxide concentration. 
in the range of $0 \cdot 20-1.00 \mu \mathrm{M}$. The linear regression equation is $I_{\mathrm{pc}}(\mu \mathrm{A})=-20.48 C(\mu \mathrm{M})-24.50$ with a correlation coefficient of 0.998 . The detection limit (signal to noise is 3 ) and the sensitivity are $0 \cdot 15 \mu \mathrm{M}$ and $20.48 \mu \mathrm{A} \mu \mathrm{M}^{-1}$, respectively. A comparison of the performances of different electrochemical sensors for hydrogen peroxide shows that this detection limit is comparable to that reported recently (Binuclear Cd(II)-IL/CPE: $0 \cdot 15 \mu \mathrm{M}^{29}$ and $\mathrm{La}(\mathrm{III})-\mathrm{IL} / \mathrm{CPE}$ : $\left.0 \cdot 11 \mu \mathrm{M}^{30}\right)$, but higher than that achieved in earlier reports $\left(10 \mathrm{pM}^{38}, 0.5 \mathrm{nM}^{39}\right.$ and $\left.0.3 \mathrm{nM}^{40}\right)$ in which other modified electrodes were used.

Compared with other modified film electrodes, the Cd-IL/CPE showed high stability. When the potential range was maintained in the same range, it was stable over 200 cycles at a scan rate of $0 \cdot 10 \mathrm{~V} \mathrm{~s}^{-1}$ and the current response remained almost unchanged. When the Cd-IL/CPE was stored at room temperature for at least 2 months, the current response decreased only by $2 \cdot 1 \%$.

\section{Conclusions}

In summary, a new ionic liquid $\left[\left(\mathrm{C}_{4} \mathrm{H}_{9}\right)_{2}-\right.$ bta $]\left[\left(\mathrm{C}_{4} \mathrm{H}_{9}-\right.\right.$ bta) $\mathrm{CdCl}_{3}$ ] was synthesized and its structure determined. The anion is composed of a metal coordination entity. The Cd-IL/CPE showed good electrocatalytic activity towards the reduction of hydrogen peroxide. The detection limit and the sensitivity are $0.15 \mu \mathrm{M}$ and $20.48 \mu \mathrm{A}_{\mu} \mathrm{M}^{-1}$. The advantages of the $\mathrm{Cd}-$ IL/CPE are stability, good catalytic activity, low detection limit and simplicity of preparation, which are important for practical application as electrochemical sensors.

\section{Acknowledgement}

This work was supported by the Natural Science Foundation of Shandong Province (No. Z2007B01), P. R. China.

\section{Supplementary information}

Crystallographic data of the structural analysis have been deposited at the Cambridge Crystallographic Data Centre, CCDC reference number 702326. Copies of this information can be obtained free of charge from: The Director, 12 Union Road, Cambridge, CB2 1EZ, UK (fax: +44-1223-336033; e-mail: deposit@ccdc.cam.ac.uk or http://www.ccdc. cam.ac.uk).

\section{References}

1. Welton T 1999 Chem. Rev. 1223

2. Sheldon R 2001 Chem. Commun. 2399

3. Visser A E, Swatloski R P, Reichert W M, Davis J H, Rogers R D, Mayton R, Sheff S and Wierzbicki A 2001 Chem. Commun. 135

4. Ludwig R and Kragl U 2007 Angew. Chem. Int. Ed. 466582

5. Taubert A 2005 Acta Chim. Slov. 52183

6. Antonietti M, Kuang D, Smarsly B and Zhou Y 2004 Angew. Chem. Int. Ed. 434988

7. Biswas K and Rao C N R 2007 Chem. Eur. J. 13 6123

8. Thirumurugan A 2007 Bull. Mater. Sci. 30179

9. Itoh H, Naka K and Chujo Y $2004 \mathrm{~J}$. Am. Chem. Soc. 1263026

10. Buhler G and Feldmann C 2004 Angew. Chem. Int. Ed. 454864

11. Parnham E R and Morris R E 2007 Acc. Chem. Res. 401005

12. Parnham E R and Morris R E 2006 J. Mater. Chem. 162208

13. Parnham E R and Morris R E 2006 Chem. Mater. 18 4882

14. Lin Z, Wragg D S, Warren J E and Morris R E 2007 J. Am. Chem. Soc. 12910334

15. Cooper E R, Andrews C D, Wheatley P S, Webb P B, Wormald P and Morris R E 2004 Nature 4301012

16. Seddon K R 1997 Chem. Technol. Biotechnol. 68351

17. Huddleston J G, Visser A E, Reichert W M, Willauer H D, Broker G A and Rogers R D 2001 Green Chem. 3156

18. Reichert W M, Holbrey J D, Vigour K B, Morgan T D, Broker G A and Rogers R D 2006 Chem. Commun. 4767

19. Kirchner B and Seitsonen A P 2007 Inorg. Chem. 46 2751

20. Denis G G, Konstantin A L, Mikhail Y A, Yakov S V, Elena I L and Alexander S S 2005 Cryst. Growth Des. 5337

21. Lee C K, Hsu K M, Tsai C H, Lai C K and Lin I J B 2004 Dalton Trans. 1120

22. Chiou J Y Z, Chen J N, Lei J S and Lin I J B 2006 J. Mater. Chem. 162972

23. Dullius J E L, Suarez P A Z, Einloft S, Souza R F, Dupont J, Fischer J and Cian A D 1998 Organometallics 17815

24. Jin C M, Twamley B and Shreeve J M 2005 Organometallics 243020

25. Lin I J B and Vasam C S 2005 J. Organomet. Chem. 6903498

26. Thirumurugan A and Rao C N R 2008 Cryst. Growth Des. 81640

27. Martin J D, Keary C L, Thornton T A, Novotnak M P, Knutson J W and Folmer J C W 2006 Nature 5271

28. Tang S and Mudring A V 2009 Eur. J. Inorg. Chem. 1145

29. Zhuang R R, Jian F F and Wang K F $2009 J$. Organomet. Chem. 6943614 
30. Wang K F, Jian F F and Zhuang R R 2009 Dalton Trans. 4532

31. Sheldrick G M, SHELXTL 6.10, Bruker AXS Inc., Madison, Wisconsin, USA, 2000

32. Wilson A J 1992 International table for X-ray crystallography (Dordrecht: V. C, Kluwer Academic Publishers)

33. Brammer L, Bruton E A and Sherwood P 2001 Cryst. Growth Des. 1277

34. Aakeröy C B, Evans T A, Seddon K R and Pálinkó I 1999 New J. Chem. 23145
35. Vila J, Gines P, Pico J M, Franjo C, Jimenez E, Varela L M and Cabeza O 2006 Fluid Phase Equilib. 242141

36. Wang K F, Jian F F, Zhuang R R and Xiao H L 2009 Cryst. Growth Des. 93934

37. Wang B and Dong S 2000 Talanta 51565

38. Salimi A, Miranzadeh L, Hallaj R and Mamkhezri H 2008 Electroanalysis 201760

39. Mizutani F, Ohta E, Mie Y, Niwa O and Yasukawa T 2008 Sens Actuators, B 135304

40. Xiao F, Zhao F Q, Zhang Y F, Guo G P and Zeng B Z 2009 J. Phys. Chem. C 113849 